\title{
Women and sexuality in nineteenth century Ireland
}

\section{Dympna McLoughlin University College Cork}

\begin{abstract}
As in Europe generally, there was a spectacular range of sexual relatior si: in 19th century Ireland, thus challenging the stereotype of a courty: exceptional chastity and prudery. Economic factors played a pivotal sele Irish women's sexual expression. Women of property had to be ser: circumspect in their behaviour. Women of different classes and circumstarces could behave differently in entering short- or long-term liaisons, with men of their own or indeed higher social class. These women' essentially drew up their own sexual contracts. However, by the late 19th century, there was less and less tolerance of sexual diversity and of women initiating their own destiny. This period $(1880 \mathrm{~s}+)$ witnessed the triumph of respectability. Henceforth, there was only one acceptable life path for normal women marriage and motherhood - and a diminishing tolerance for any type of sexual diversity.
\end{abstract}

Views of femininity in the eighteenth and early nineteenth centuries initially varied according to a woman's socio-economic position but underwent gradual change so that by the 1880 s there were universal classless notions of women's innate nature and appropriate feminine behaviour (Note 1; $\mathrm{O}$ Reilly, 1877). Set codes of feminine conduct were associated with public order, social stability and the proper functioning of society.

There were essentially three main characteristics of a respectable woman, regardless of class. The first was that she have an overwhelming desire to marry, remain faithful in a life-long union, and remain subordinate and dependent in that relationship. Secondly, the woman's natural sphere was the domestic where she engaged in reproductive and not productive tasks. Mothering became newly defined and confined and the widespread practice of wetnursing became severely curtailed. Thirdly, and most significantly, women's sexuality was totally contained in marriage. This was not true for men and there was public leeway for male "indiscretions". Since women were believed to have no sexual desire they were compensated with a superior "moral nature" and a heightened sense of right and wrong in sexual matters (Note 2). This belief made women into a moral

Correspondence address: Dr. Dympna McLoughlin, Department of Geography, University College Cork, Republic of Ireland. 
army; not only were they responsible for their own shortcomings, they were also responsible for the shortcomings of their menfolk. Failings of women (especially of a sexual nature) were viewed as much more serious as the same failing in a man. There was a belief that a man could be easily led astray by a beguiling woman and since men had little powers of resistance (since they were creatures driven by desire), they could do little else but succumb. Thus the justification of the double standard was laid on biology, obscuring the strong economic factors which influenced the sexual behaviour of nineteenth century Irishwomen. These economic factors will constitute the second part of this paper. As a prelude, some comments on the widespread belief of the absence of sexual activity outside marriage in the nineteenth century are pertinent.

\section{A COUNTRY NOTED FOR ITS PURITY?}

Nineteenth century Irish demographic trends are so frequently articulated as to be accepted fact. In the pre-famine period "Ireland was a country of young marriage, and consequently high marital fertility. After the famine the country was characterised by postponed marriage and a uniquely high level of permanent celibacy" (Connell, 1950). Marital fertility, however, continued to be high by Western standards. In so far as the crude birth rate fell in Ireland in the latter part of the nineteenth century it was through a combination of low marriage rates and high fertility and not, as in Britain, by a reduction of marital fertility (Langer, 1975).

This demographic pattern was sustained totally by economic forces. The reckless abandon in which people married before 1845 changed with the advent of the famine. The consolidation of holdings, commercial farming and the complete eradication of the cottier class were significant characteristics of the post-famine economy. High marital fertility was sustained by the siphoning-off force of emigration and a peculiar respectability. attached to the celibate state. Essentially, one son inherited the family home, one daughter was provided with a dowry and married, and the remainder of the family had to find their own way in the world. A further unique demographic feature of nineteenth century Irish society was its very low illegitimacy rates by European standards. In 1864, the first year that official statistics became available, S.J. Connolly has asserted that the proportion of illegitimate to total births was $3.8 \%$ and in the first seven years of civil registration it remained constant at 3.2\% (Connelly, 1979). By European standards this was very low indeed as in France the rate was between $6 \%$ and $7 \%$, in Scotland between $6 \%$ and $9 \%$, Germany $8 \%$ and $9 \%$, Austria $13 \%$ and in England and Wales between $5 \%$ and $6 \%$. 
Therefore, Ireland was a country with low nuptiality, high marital fertility, minimal illegitimacy, large scale emigration and celibacy. Lending further credibility to this view were the testaments of nineteenth century travellers such as Dickens and Kohl. Their assertions of a country filled with virtuous virgins, widespread abstinence and chastity gladdened the hearts of nationalists and clerics alike in the twentieth century. They believed in the superior sexual discipline and control of the Irish who stood aloof from the spiralling trends of bastardy and illegitimacy which was an accepted and well-documented part of European demographic history. The Irish disdain for sex became an accepted fact and we became deluded by our own mythmaking.

It is naive to accept that this tightly ordained structure of delayed inheritance, a dowry for one daughter and the easy disposal of the rest of the family through permanent celibacy, or the seeking after a religious vocation, operated without abberation or discord. Scepticism about the low illegitimacy rate and, by implication, the absence of sexual activity outside marriage, must be challenged in the Irish context considering the following range of factors.

1. In all countries a high level of marital fertility was accompanied by a similar level of extra-marital fertility. Therefore we have been remiss in Ireland in only looking at one aspect of the equation - marital fertility without questioning whether there was a non-marital equivalent. After long immersion in the various sources dealing with the behaviour of Irishwomen in the 19th century, it is worth posing the question. Was the constant articulation of the purity of Irishwomen a warning to them rather than an accurate reflection of reality?

2. In Ireland there was a thriving trade in prostitution not only in the cities but also in the garrison towns. In 1870 there were 3,255 women arrested as prostitutes. In 1845 , William Logan, a Philanthropist, ascertained that there were 85 regular brothels in Cork and 356 public prostitutes. Luddy states that a rough estimate of the extent of prostitution in Ireland may be gleaned from the Metropolitan police records who list between 300 and 3,000 prostitutes annually (Luddy, 1990). This figure from the capital city does not include the wretched creatures such as the "curragh wrens" who trailed around after military garrisons. The passing of the Contagious Diseases Acts in Ireland in 1864, 1866 and 1869 and their implementation in Dublin, Cork, Cobh and the Curragh and the subsequent campaign for their repeal, reveals not only a double standard of sexual morality, but a widespread public awareness of prostitution and the sale of sex. 
3. Alongside the observations of the exceptional chastity of the Irish were parallel statements shocked at the ribaldry and sexual explicitness of games meant for the amusement of mourners at wakes. Corish has noted that the Drogheda synod of 1641 complained "through the evil of some idle fellows and jesters, there are bawdy songs, wanton mimes, and after dark filthier work of darkness" (Corish, 1985). He criptly adds that the Catholic Church had a few centuries of effort still ahead. Clerical disapproval of the practice had little impact, as Connolly documents the same "indecent shows and postures" in the presence of the corpse in the pre-famine period (Connolly, 1982). Whilst accepting the many testimonies as to the enduring and intimate nature of these sexual frolics at wakes, some may argue that this was an occasional and symbolic form of (simulated ?, actual?) sexual release. Looking to another source, Irish folklore, one will find that this was not the case. Matters of a sexual nature were not sanitised out of the folk memory. Women who were impatient with shy lovers administered love potions to them which "set the man mad and afterwards he had to marry the girl", and for the "lethargic" who were unable to initiate or complete sexual relations there were also particular remedies (Note 3). Sex was a vital and pleasurable act in both an affirmation and a continuation of life. Celibacy or abstinence were not celebrated in this tradition.

4. How did the "gentleman's miss" fare in these statements about purity. In nineteenth century Ireland, the "gentleman's miss" was public knowledge. She was a women of lower socio-economic rank who was prepared to sell her sexual favours to a gentleman on her own terms.

5. In the minute books of the various Poor Law Unions there are letters from emigrant women, previously assisted to emigrate to North America and Australia, who sought children left behind in the workhouse. These women were sent out to the colonies as single unmarried individuals, but, on becoming settled and earning a livelihood, sent for their children. For example, in 1853, Mary Lewis sent five pounds for the passage out of her child Richard Evans who had spent five years in the workhouse(McLoughlin, 1988). These petitions, and there were many of them, reveal the extent which women could conceal unapproved aspects of their lives (illegitimate offspring) from officialdom. In turn, there were many complaints from the colonists that these young, single, virtuous Irishwomen sent out to them were the most impure and immoral of characters and "wanted no more of the shovelled out refuse of Irish Workhouses sent to their shores" (Note 4). Indeed these schemes might be an early example of the Irish exporting their problems so that the stereotype of a virtuous and unblemished womanhood remained intact. 
6. The presence of the Dublin foundling hospital in the eighteenth century, the use of the workhouse as a dumping ground for unwanted children in the nineteenth century, as well as the many private institutions and orphanages for unwanted and deserted children, would suggest sexual activity outside approved social norms, or else practices unable to be sustained in the emerging economic order.

7. Details of illegitimacy and illicit sexual contact are not to be found in the official records of the age. The fact remains that illegitimacy, infanticide and the concealment of births did not come under official scrutiny and are thus presumed not to have existed. Even a superficial of alternative sources such as the Poor Law Inquiry of 1836 (a magnificent source which deals with the lives of ordinary people) reveals that this was not the case (Note 5; McLoughlin, 1988).

To accept the notion that the Irish remained immune from strong and definite demographic trends in Europe is to glide over a vital area of Irish life and to obscure vital elements in the history of women. This includes the realm of work, marriage, sexuality, childbirth and childrearing, and indeed for many, their very survival.

\section{SEXUAL TRANSACTIONS IN NINETEENTH CENTURY IRELAND}

There was not a single norm of sexual alliance in Ireland in this period, but rather a whole series of relationships both casual and permanent (see Figure 1). In the "gentleman's miss" situation, the "miss" had the power to define the terms of her sexual involvement including provision for the children of the union. By far the commonest sexual alliance was between men and women of the very poorest ranks of society. These were termed "irregular unions" since they were not recognised by either church or state. However, these destitute paupers believed themselves to be married, since they had paid a small sum of money to a "couple beggar" and in return he performed a rudimentary ritual over them. It was the joint effort of both man and woman in their unions which made for their own survival and that of any children they might have had. These unions varied in duration. If one partner was deemed to be unsatisfactory the alliance was terminated. The formal exchange of a chaste dowered woman by her father to a man with land or property was slowly becoming the only acceptable mode of sexual alliance from 1850 onwards. The chastity of the woman sealed the contract and ensured only a legitimate male heir had a claim to the land. These were respectably married women, to be envied in their esteemed position as wives and more importantly in the Irish context, as mothers. There was the 
same degree of contempt for women who sold sex in transient contact as there was for spinsters who remained on as a unwelcome burden with their married siblings. Women who did trojan work in schooling, in the administration of hospitals and asylums as religious sisters were hardly recognised at all as were the other women who were failing to conform to the dominant stereotype of an appropriate feminine destiny.

Three types of sexual alliances will be briefly outlined- the "gentleman's miss", very poor women with illegitimate children, and finally, aspiring middle class women.

Figure 1. Sexual Transactions in nineteenth century Ireland

Sex Power

Survival

Formal exchange

Informal/Transient Contact

Forfeit

Pending (hopefully)

Satisfied (not pending at all)

Ill, deviant but acknowledged

Unacknowledged

Gentleman's Miss

Irregular Unions

Marriage

Prostitution

Nuns

Heterosexual Contact

Homosexual relationships

"Self-polluters"

"Hysterics" "Mad"

Those that abandoned children

Women guilty of infanticide

\section{The Gentleman's Miss}

The interest of a gentleman in a woman was her passport to a comfortable life. His sexual pleasure with her, even if shortlived, meant that she had his lifelong interest and protection. She and their children were usually given a small cottage and land while the gentleman lived and, on his death, she obtained legal title to these and sometimes even extras such as orchards or rights of way (Note 6). Sometimes this union was lifelong, giving rise to subsequent disputes over the legitimacy of the heirs; often it was only for a few years. In the latter cases the gentleman often provided a marriage partner for his former mistress. It was usually someone of his acquaintance of an artisan or labouring background, men for whom the promise of money and land was irresistible. There was never difficulty in procuring husbands for these women, despite their very public loss of virtue, and their very comfortable economic position no doubt overcame prejudices. In general

"a girl that has been seduced by a gentleman, is not looked upon as been altogether so impure as one who has been led into error by one in her own station.....the leniency of opinion arose from the possibility that she had weighty reasons for her yielding." (Note 7). 
Overall there was a kind of grudging admiration of this woman's economic astuteness, and her ability to take care of her self and her own interests. She never became an outcast as did the middle class women who broke with the conventions of acceptable behaviour of both their sex and their class.

\title{
Pauper Women with Bastards
}

Few were concerned with the fate of pauper women as they carried on with their lives, making deliberate efforts to make themselves invisible to official eyes. Their sexual behaviour was deemed to be outside the bounds of decency and respectability and thus not worthy of public interest or scrutiny. In 1836, in Skull in County Cork it was noted that

\begin{abstract}
"circumstances of having an illegitimate child is thought less of in this parish than elsewhere. They are all too much reduced and in too great poverty to feel the distinction. There is very little feeling of respectability among them." (Note 8 ).
\end{abstract}

In the industrial north-east of Antrim, it was noted in the same report that "the crime of being the mother of a bastard and the misfortune of being a bastard are little thought of here" (Note 9). Industrial context was very different from the rural one. Land, lineage and virtue were not the prerequisites to wealth and respectability. In an industrial context, fortunes could be easily amassed and status was achieved rather than ascribed.

\section{The Middling Sorts with Bastards}

If a woman was impregnated through pre-marital sexual relation, and the man refused to marry her, she was in a most wretched predicament. Her only chance of redemption was if her father provided an extra large dowry "in order to cover her disgrace" (Note 10). The size of the marriage dowry, of anything up to one hundred pounds, was viewed as the financial worth of female purity and virtue. However, in practice, the colossal sum paid to compensate for lost virtue only served to circumscribe the conduct of the middling sorts even more. There could be no frolicking with any man, since an "accident" of any type could render them in a most vulnerable situation. If the man refused to marry them and if their fathers were unable or unwilling to provide them with a dowry then they remained unmarriageable and a humiliation upon the family as well as an economic burden. These women could either conceal their illegitimate offspring, or else remain absolutely celibate until their nuptials. Increasingly after 1840 , the middling sorts of folk, farmers in particular, stressed the absolute importance of female virtue. An unvirtuous daughter could be the ruination of an otherwise thrifty and farseeing man. 
The daughters of the thrifty and wealthy were continuously watched and gossiped about. This gossip served as a social control on their actions. It also served as a means of letting mercenary-minded men know when somebody's daughter had been impregnated and abandoned and the financial booty that might be in the offering for any man willing to repair the damage by a "subsequent marriage" (Note 11). In this sense, sexual prudery in nineteenth century Ireland had little to do with the church and all to do with the economics of the emerging middle class. Delayed sexual intimacy for women until marriage was thus too emerge as a most important social more, a more that was vigorously enforced in almost every aspect of life.

Few men were willing to place their wealth and status at risk by attempting to conceal their daughter's shame. Economics, and not sentiment, were the main issues here. There was public contempt also for the man who took a pregnant bride (even if he was the father). He was known as a "purchased husband", a "mean fellow" or it was simply stated that he was paid to marry the woman. Generally there men were believed to demean themselves by voluntarily participating in the woman's disgrace and therefore to be judged as just as morally corrupt. For women who did manage to find a marriage partner all they gained was the slightest shred of respectability. Under this cloak of marriage they could be endlessly exploited and abused without sympathy or comment. Having lost caste there was little social concern with her subsequent fate.

A woman of this class who became pregnant outside marriage could never redeem herself. They were

"universally looked upon with contempt. They are considered to have inflicted a deep disgrace, not only upon themselves but upon their families and though they may not be driven on the world from their father's house still their frailty remains a constant source of bickering and reproach at home." (Note 12).

The unmarried pregnant woman was in a most wretched condition, depending on the charity of her family for her support. Families less tolerant of her disgrace cast her away from them to become a vagrant. Having no skills and having been shunned by decent society many had to resort to the workhouse or prostitution. Whatever path they chose their's was a most difficult lot.

An awareness of the vulnerability of pregnancy outside marriage was acute for many young women and the fear of their families' wrath coupled with the astute realisation of their lack of employment prospects in Ireland made many of them extremely conservative in their courtships. They was no prudish maidens or sheltered daughters. Instead they were reared with an awareness of the seriousness of sexual laxity outside 
marriage as members of an aspiring class. They further realised that they had no guarantee of their fathers paying a dowry for them and that the inhospitable road and a vagrant life was more often than not the price to be paid for sexual aberration.

\section{CONCLUSION}

The purpose of this short piece is to question the myth of nineteenth century Ireland as some idealised asexual age, where there was no sexual relations outside marriage, no prostitution, infanticide, or child abandonment nor indeed any forms of sexual deviance. This was not the case. These are issues which long predate the nineteenth century. In the Irish situation we have ignored them totally, filtered them (along with social history generally) out of a very politicised history and thus incorrectly assumed they are of recent origin.

In the nineteenth century there was great variety and complexity in women's lives. The single life pattern for women, of marriage, husband and children was only becoming widespread in the 1880 s and was ultimately to reach its fullest expression in the newly independent Ireland and most especially in the 1937 constitution. Here many roles had been pared away totally, and women received only partial recognition not as citizens but as mothers. Now in the 1990 s as mothers we are most suspect, with recent debates centering around freedom of information as well as freedom of movement. It is thus important to seek out women's historical and intellectual legacy in such an inhospitable age.

\section{NOTES}

1. For an excellent example of a prescriptive manual dealing with appropriate female behaviour in every context see $O$ Reilly (undated; query 1877).

2. In the Irish context this sense of the superior morality of women had little impact in the social sphere. In the American context, Rosenberg has argued it functioned quite differently. American feminists built on their moral right to a voice in the public sphere especially in matters relating to children to eventually gain enfranchisement.

3.See the records of the Irish Folklore Commission, in University College Dublin. 4. See the Minute Books of the Dublin South County Poor Law Union, dated 6th February, 1864.

5. Reports of His Majesty's Commissioners for inquiring into the condition of the Poorer classes in Ireland (hereafter Poor Law Inquiry); First Report, H.C. 1835 (369).

6. For an example see the Indenture made between William Barrett of Culleenamore in Sligo and Letitia Begley of Culleenamore, Spinster. Letitia received a lease for three lives and a considerable amount of property in a will dated 2 March 1822. The 
indenture concludes "and it is further agreed that the said Letitia Begley can only have the power of bequeathing the said demesne premises to the children of the said William Barrett begotten on the body of the said Letitia Begley and to no other person whatsoever." Letitia placed her mark in agreement with the terms in the indenture.

7. Poor Law Inquiry, County Clare Parish Kilfarboy, including town of Miltown Malbay, p. 78.

8. Poor Law Inquiry, County Cork, Parish Schull, p. 69.

9. Poor Law Inquiry, County Antrim, Parish Resharkin, p. 38.

10. Poor Law Inquiry, County Carlow, the parish of Aghade and Ballin, p. 57. Also see Barony of Kilkenny west, p. 68.

11. A subsequent marriage was marriage after conception of a child, in other words to a pregnant bride.

12. Poor Law Inquiry, County Kildare, Parish of Kilcock, p. 64.

\section{REFERENCES}

Connell, K.H. (1950). The Population of Ireland, 1750-1845. Oxford: Oxford University Press.

Connelly, S.J. (1979). Illegitimacy and pre-nuptial pregnancy in Ireland before 1864: The evidence of some Catholic parish registers. Irish Economic and Social History Joumal, 6, 5-23.

Connelly, S.J. (1982). Priests and People in Pre-Famine Ireland 1780-1845. Dublin: Gill and MacMillan.

Corish, P.J. (1985). The Irish Catholic Experience - A Historical Survey. Dublin: Gill and MacMillan.

Langer, W.L. (1975). The origins for the Birth Control Movement in England in the early nineteenth century. Joumal of Interdisciplinary History, 4, 669686.

-uddy, M. (1990). Prostitution and rescue work in nineteenth century Ireland. In M. Luddy \& C. Murphy (Eds), Women Surviving. Dublin: Poolbeg Press.

McLoughlin, D. (1988). Shovelling out the paupers. Female emigration from Irish workhouses to North America. Unpublished Ph.D. dissertation, Syracuse University, New York.

O'Reilly, B. (undated; query 1877). The Mirror of True Womenhood, A Book of Instruction for Women in the World. Dublin: M.H. Gill and Son Ltd.

Rosenberg, C.S. (1985). Disorderly Conduct: Visions of Gender in Victorian America. Oxford: Oxford University Press.

Dympna McLoughlin lectures in history at Mary Immaculate College of Education in Limerick and at the Department of Geography, University College Cork. 